\title{
Combined Effect of Methanol Extract of Persea americana Seeds and Cassia alata Leaves Against Staphylococcus epidermidis
}

\author{
Morina Adfa ${ }^{*}$, Ni Made Candra Gusatyana, Andre Mudyanto, Avidlyandi \\ Avidlyandi, Dwita Oktiarni, Salprima Yudha S. \\ Department of Chemistry, Faculty of Mathematics and Natural Sciences, University of Bengkulu, \\ Jalan W.R. Supratman, Bengkulu 38371, Indonesia \\ *e-mail:morina@unib.ac.id
}

\begin{abstract}
S
The aim of this study was to analyze the individual and combined antimicrobial effects of avocado seed (Persea americana) and ketepeng cina leaf (Cassia alata) methanol extracts against Staphylococcus epidermidis using the Kirby Bauer assay. Variations in the proportions of $P$. americana to C. alata (A: K) extracts were $4: 0 \mathrm{mg} / \mathrm{mL}, 8: 0 \mathrm{mg} / \mathrm{mL}, 12: 0 \mathrm{mg} / \mathrm{mL}, 0: 4 \mathrm{mg} / \mathrm{mL}, 0$ : $8 \mathrm{mg} / \mathrm{mL}, 0: 12 \mathrm{mg} / \mathrm{mL}, 4: 4 \mathrm{mg} / \mathrm{mL}, 4: 8 \mathrm{mg} / \mathrm{mL}, 4: 12 \mathrm{mg} / \mathrm{mL}, 8: 4 \mathrm{mg} / \mathrm{mL}$, and $12: 4 \mathrm{mg} / \mathrm{mL}$ respectively, and the tests were executed in four replicates. The positive controls used were Clindamycin and Chloramphenicol, while the negative was DMSO. After 24 hours of incubation, zones of inhibition were exhibited by the experimental group and positive control, but not by the negative test. The largest diameters from the methanol extract of $P$. americana seeds and $C$. alata leaves singly at strengths of $12 \mathrm{mg} / \mathrm{mL}$ were $5.96 \mathrm{~mm}$ and $9 \mathrm{~mm}$, while the mixture at various concentrations showed the pattern of growth organism as an indifferent (additive) effect.
\end{abstract}

Keywords: Antibacterial, combination, Cassia alata, Persea americana, Staphylococcus epidermidis

\section{INTRODUCTION}

The human skin is the area of the body most frequently affected by microbial infections, especially acne. This is a disease appearing on the surface of the face, neck, chest, and back caused by the obstruction of skin pores by excessive fat deposits resulting from overactive oil glands. Inflammation during this condition is triggered by Staphylococcus epidermidis observed to develop in oil glands, resulting in irritation around the infected area, followed by swelling, eruption and the emergence of inflammation in the tissue. This ailment is due to elevated levels of hormonal secretions and occurs generally in young people, particularly teenagers and during puberty when a child experiences transformations to facilitate growth into adulthood [1].

The first-line therapy for patients with moderate to severe inflammatory acne are oral antibiotics. However, the long-term use of these drugs lead to bacterial resistance. Efforts therefore, are encouraged to inhibit $S$. epidermidis growth through the use of herbal medicine. The frequency of herbal medicine usage is on the rise as a result of a proven efficacy in the treatment of various diseases, a long history of use, fewer side effects, and affordability [2].
Presently, the combination of several plants and the consumption of herbal drugs without clear scientific data and clinical evidence has become a common habit of the Indonesian people. These concoctions often exert synergistic effects exceeding the individual medicinal performance, and are prepared from various plant extracts, infused with antibiotics, and/or other chemicals [3]. Therefore, avocado seeds (Persea americana) and ketepeng cina leaves (Cassia alata) are examples of natural ingredients reported to possess antibacterial effects, and also to potentially inhibit the growth of the acnecausing $S$. epidermidis.

Avocado seeds have been demonstrated to possess toxic, antibacterial, anti-inflammatory, anticancer, antidiabetic, and anti-fungal effects through scientific research [4]. The results of phytochemical screening showed these seeds contained flavonoids, tannins, alkaloids, anthocyanins, polyphenols, triterpenoids, quinones, saponins, and steroids [5]. [6] Furthermore, research conducted reported the antibacterial activity of the ethanol extract of Shepard avocado seeds $(P$. americana) against Gram-positive and negative bacteria, as well as yeast, including Enterobacter aerogenes (MIC $125 \mu \mathrm{g} / \mathrm{mL}$ ), Citrobacter freundii (MIC $145.8 \mu \mathrm{g} / \mathrm{mL}$ ), Listeria monocytogenes (MIC 
$166.7 \mu \mathrm{g} / \mathrm{mL}$ ), Pseudomonas aeruginosa (MIC $166.7 \mu \mathrm{g} / \mathrm{mL}$ ), Salmonella enteritidis (MIC 208.3 $\mu \mathrm{g} / \mathrm{mL}$ ), Enterococcus faecalis (MIC $250 \mu \mathrm{g} / \mathrm{mL}$ ), $S$. typhimurium MIC $250 \mu \mathrm{g} / \mathrm{mL})$, Staphylococcus aureus (MIC $416.7 \mu \mathrm{g} / \mathrm{mL}$ ), S. epidermidis (MIC > $500 \mu \mathrm{g} / \mathrm{mL}$ ), and Escherichia coli (MIC > 500 $\mu \mathrm{g} / \mathrm{mL})$.

In addition, ketepeng cina $(C$. alata $)$ is another natural ingredient with antibacterial activity. This herb demonstrates a potential for the treatment of skin diseases including ringworm, eczema, pruritus, itching, scabies, ulcers and other related diseases. The plant is employed by pulverizing and applying on affected areas, and is rich in anthraquinones, phenols, tannins, saponins, alkaloids, steroids, flavonoids and carbohydrates [9]. Furthermore, the aqueous extraction of $C$. alata leaves revealed antimicrobial efficacy against $P$. aeruginosa, S. epidermidis, S. aureus, and Bacillus subtilis [8]. Several distinct compounds isolated from these leaves have also exhibited activity against various bacteria including Streptococcus pyogenes, Bacillus megaterium, Shigella flexneri, Escherichia coli, $P$. aeruginosa and S. typhi [9].

The antibacterial activity produced by the mixture of methanol extracts from avocado seeds and ketepeng leaves is worthy of note, as the effect of this combination on $S$. epidermidis growth has been largely unknown.

\section{MATERIALS AND METHODS}

\section{Extraction}

The avocado ( $P$. americana) seeds and ketepeng cina leaves $(C$. alata) were reduced into smaller pieces and dried to a weight of $1.44 \mathrm{~kg}$ and $1.14 \mathrm{Kg}$, respectively, and then macerated with methanol for 4 days. The result of this process after filtration was evaporated with a rotary evaporator to generate a thick extract and further processed six times with methanol to obtain crude methanol extracts.

\section{Sterilization of Equipment and Materials}

The apparatus used in this study comprised petri dishes, Erlenmeyer flask, and beakers, sterilized in an oven at a temperature of $160{ }^{\circ} \mathrm{C}$ for 2 hours. The MHA and MHB media were sanitized with the use of an autoclave at $121^{\circ} \mathrm{C}$ for 15 minutes. Finally, the needles and tweezers were disinfected by placement directly above the flame before every use.

\section{Preparing Staphylococcus epidermidis Suspensions}

Test samples of the bacteria were obtained from the Microbiology Laboratory of the Bogor Agricultural University (IPB). The oblique agar media were streaked with $S$. epidermidis bacterial culture and incubated at $37{ }^{\circ} \mathrm{C}$ for 24 hours. Then, 1 ose the rejuvenated bacteria were added into $100 \mathrm{~mL}$ sterilized MHB, stirred without heating at a very low speed for 1 hour, and incubated finally at $37^{\circ} \mathrm{C}$ for 24 hours. The following day, a cloudy solution containing the $S$. epidermidis colonies was generated, and the suspended bacteria diluted with MHB to yield an absorbance between 0.08-0.13 (0.5 McFarland) at a wavelength ( $\chi)$ of $625 \mathrm{~nm}$ [7].

\section{Preparation of Test Sample Solutions}

This was performed by weighing out the crude methanol extracts of avocado seeds and ketepeng cina leaves with $0.004 \mathrm{~g}, 0.008 \mathrm{~g}$, and $0.012 \mathrm{~g}$ followed by the addition of the DMSO until a volume of $1 \mathrm{~mL}$ to generate concentrations equivalent to $4 \mathrm{mg} / \mathrm{mL}, 8 \mathrm{mg} / \mathrm{mL}$ and $12 \mathrm{mg} / \mathrm{mL}$ were obtained. Meanwhile, the antibiotics Clindamycin and Chloramphenicol were prepared to create concentrations of $0.25 \mathrm{mg} / \mathrm{mL}$ and used as positive controls.

Preparation of the Combined Methanol Extract Solutions from Avocado Seeds (Persea americana) and Ketepeng cina Leaves (Cassia alata.)

Volumes of $50 \mu \mathrm{L}$ were withdrawn from the previously prepared methanol extracts of each plant sample, mixed and then homogenized using Vortex. The ratios of $P$. americana to $C$. alata $(\mathrm{A}: \mathrm{K})$ extracts were 4: $0 \mathrm{mg} / \mathrm{mL}, 8: 0 \mathrm{mg} / \mathrm{mL}, 12: 0 \mathrm{mg} / \mathrm{mL}, 0: 4$ $\mathrm{mg} / \mathrm{mL}, 0: 8 \mathrm{mg} / \mathrm{mL}, 0: 12 \mathrm{mg} / \mathrm{mL}, 4: 4 \mathrm{mg} / \mathrm{mL}, 4: 8$ $\mathrm{mg} / \mathrm{mL}, 4: 12 \mathrm{mg} / \mathrm{mL}, 8: 4 \mathrm{mg} / \mathrm{mL}$, and $12: 4$ $\mathrm{mg} / \mathrm{mL}$.

Determination of the Combined Extracts Effect Patterns using the Paper Strip Diffusion

The synergistic effect patterns were determined with the paper strip diffusion by observing the combination outcomes after about 25 $\mu \mathrm{L}$ of each test extract was dribbled on the Whatman (No.3) paper tape with measurements of $3 \times 0.5 \mathrm{~cm}$. Following this, the paper strips were placed on the MHA agar media containing the tested bacteria by constructing angles of $90^{\circ}$ on the petri dish. Then, the dishes were incubated at $37^{\circ} \mathrm{C}$ for 24 hours [10].

\section{Antibacterial Activity Test}

This test was implemented by employing the commonly used Kirby Bauer agar diffusion and the disc diffusion technique. The sterilized MHA media at a volume of $15 \mathrm{~mL}$ was poured into a petri dish, 1 $\mathrm{mL}$ of the bacterial suspension prepared was added, and then the product was homogenized and allowed to solidify. After this, 8 discs were placed on the surface of the media, and $2.5 \mu \mathrm{L}$ test solutions, positive control, and DMSO, respectively were trickled onto the paper. The test was performed in four replicates, the Petri dishes incubated at $37{ }^{\circ} \mathrm{C}$ for 24 hours, and the diameters of the inhibition zones formed around the discs were measured with 
a caliper[11]. Meanwhile, the inhibitory response to the extracts is classified into: > $20 \mathrm{~mm}$ (Very Strong), 15-19 mm (Strong), 9-14 mm (Moderate), and $<8 \mathrm{~mm}$ (Weak) [12].

\section{RESULTS AND DISCUSSION}

\section{Extraction}

The maceration of $1.44 \mathrm{~kg}$ avocado seeds $(P$. americana) with methanol as a solvent produced an extract with a reddish-brown hue weighing $168.87 \mathrm{~g}$, alongside a yield of $11.73 \%$. Conversely, $1.14 \mathrm{~kg}$ ketepeng cina leaves $(C$. alata) macerated with methanol generated $125.32 \mathrm{~g}$ of dark-green colored extract and a yield of $10.99 \%$.

\section{Antibacterial Activity}

The methanol extracts from avocado seeds and ketepeng cina leaves were shown to inhibit $S$. epidermidis growth. Based on the results in Figure $1 \mathrm{a}$ and $1 \mathrm{~b}$, the diameter of the average inhibition zone formed around the paper disc increased with the concentration of the single extracts used in the test increased. The largest inhibition zone of the avocado seeds and ketepeng cina leaves extracts, particularly $5.96 \mathrm{~mm}$ and $9.00 \mathrm{~mm}$ simultaneously, were produced at $12 \mathrm{mg} / \mathrm{mL}$ the highest test concentration used, on an average of 4 treatments. According to [12] the average inhibition zones obtained from the extracts at the concentration of $12 \mathrm{mg} / \mathrm{mL}$ were categorized as "weak" and "moderate" respectively, for the inhibition of the acne-triggering $S$. epidermidis. Furthermore, at the lowest concentration tested revealed clear zones at $3.79 \mathrm{~mm}$ and $5.45 \mathrm{~mm}$, and both belonged to the weak category (Figure 2).

The determination of the test sample's antibacterial ability were performed by comparisons with antibiotics. [13] S. epidermidis is resistant to penicillin and methicillin antibiotics, therefore, this study used Chloramphenicol and Clindamycin as positive controls, as these drugs possess activity against the organism. Figure $1 \mathrm{a}$ and $1 \mathrm{~b}$ showed chloramphenicol to produce an average zone of $22.65 \mathrm{~mm}$, while clindamycin produced an average diameter of $29.52 \mathrm{~mm}$. Therefore, the zones of the two positive controls were obviously greater than those produced by each single test extract.

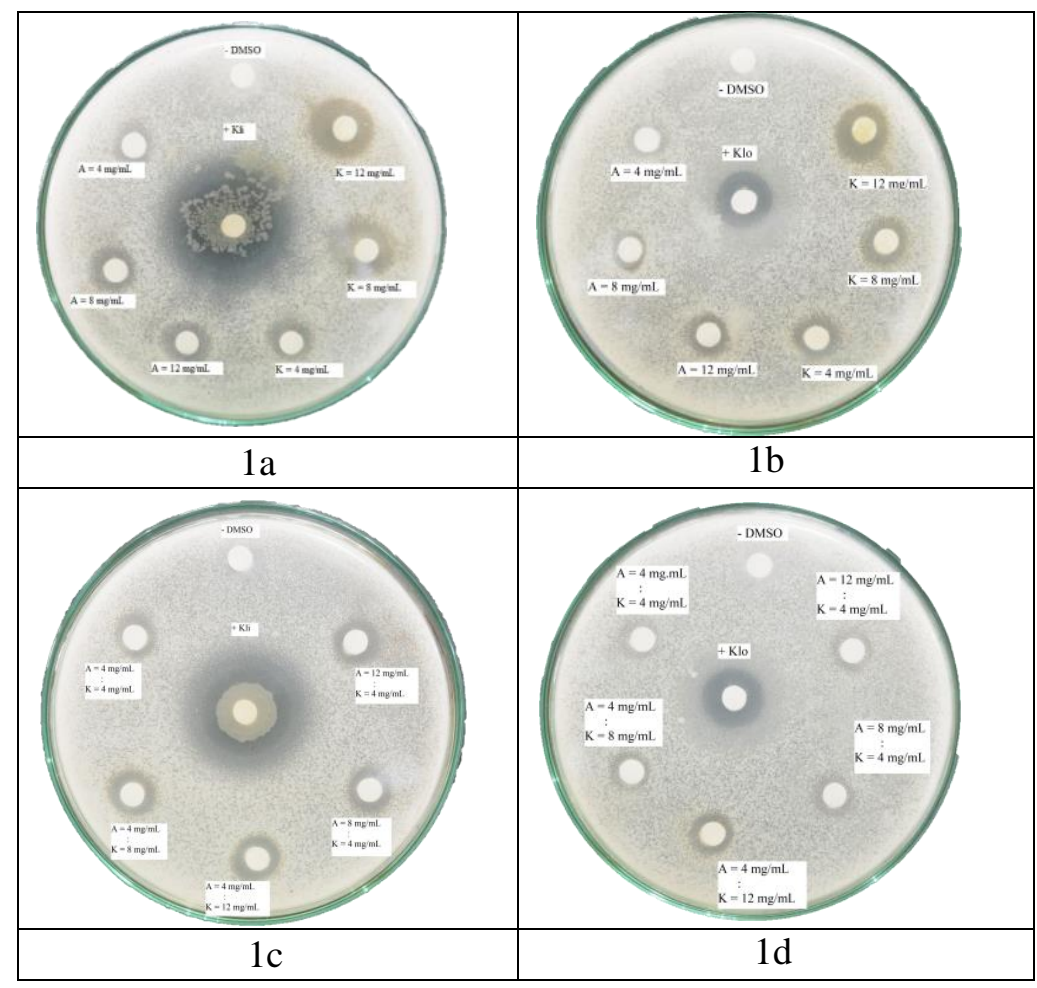

Figure 1. Antibacterial activity of the avocado seeds and ketepeng cina leaves methanol extracts against acnecausing bacteria Staphylococcus epidermidis (1a) single extract and clindamycin (1b) single extract and chloramphenicol (1c) combination extracts and clindamycin (1d) combination extracts and chloramphenicol. Note: $\mathrm{A}=$ Avocado extract; $\mathrm{K}=$ Ketepeng cina extract; (+) Kli = clindamycin, (+) Klo = chloramphenicol; (-) DMSO.

The results of the inhibition zones of the combined extracts at various test ratios are displayed in Figures $1 \mathrm{c}, 1 \mathrm{~d}$, and 2 . The zones generated by the combination of the avocado seeds (A) and ketepeng leaves $(\mathrm{K})$ extracts at ratios $(\mathrm{A}: \mathrm{K})$ of $4: 4 \mathrm{mg} / \mathrm{mL}(1$ :
1), $4: 8 \mathrm{mg} / \mathrm{mL}(1: 2), 4: 12 \mathrm{mg} / \mathrm{mL}(1: 3), 8: 4 \mathrm{mg} / \mathrm{mL}$ (2: 1$)$, and $12: 4 \mathrm{mg} / \mathrm{mL}(3: 1)$ were $4.01,5.14,5.66$, 3.81 , and $4.33 \mathrm{~mm}$, respectively. Apparently, all the test mixtures showed weak growth deterrence responses. The ratio 1: 3 generated the largest clear 
zones of all the test mixtures at a measure of 5.66 $\mathrm{mm}$. The inhibition diameters $(4.01,5.14,5.66 \mathrm{~mm})$ were observed to increase when the avocado seeds extract concentration was kept constant and ketepeng leaves extract concentration was increased. However, when the concentration of the ketepeng extract remained constant and the avocado seeds concentration increased, the diameter of the mixture interestingly fluctuated and the results were 4.01 , 3.81, and 4.33.

The areas of inhibition produced by the proportions $4: 4 \mathrm{mg} / \mathrm{mL}, 4: 8 \mathrm{mg} / \mathrm{mL}$, and $4: 12$ $\mathrm{mg} / \mathrm{mL}$ were $4.01 \mathrm{~mm}, 5.14 \mathrm{~mm}$, and $5.66 \mathrm{~mm}$ simultaneously. These diameters were all smaller in comparison to those of the ketepeng extract alone at volumes of $4 \mathrm{mg} / \mathrm{mL}, 8 \mathrm{mg} / \mathrm{mL}$, and $12 \mathrm{mg} / \mathrm{mL}$ where zones of $5.45 \mathrm{~mm}, 6.25 \mathrm{~mm}$, and $9 \mathrm{~mm}$ were observed. The diameters of the three combinations above were however greater than the $4 \mathrm{mg} / \mathrm{mL}$ individual avocado seed extract with a diameter of $3.79 \mathrm{~mm}$. In addition, the areas of the extract combination at $8: 4 \mathrm{mg} / \mathrm{mL}$ produced $3.81 \mathrm{~mm}$, also less than the zone widths produced by $4 \mathrm{mg} / \mathrm{mL}$ of ketepeng extract and $8 \mathrm{mg} / \mathrm{mL}$ of avocado seed extract with resultant diameters of $5.45 \mathrm{~mm}$ and 5.04 $\mathrm{mm}$ respectively. Furthermore, the areas of $5.45 \mathrm{~mm}$ and $5.96 \mathrm{~mm}$ generated by $4 \mathrm{mg} / \mathrm{mL}$ of ketepeng concentrate and $12 \mathrm{mg} / \mathrm{mL}$ of avocado extract were also greater than the $4.33 \mathrm{~mm}$ zone produced by the combined strength of $12: 4 \mathrm{mg} / \mathrm{mL}$.

The combined effect of integrating two test extracts has the propensity to be synergistic, indifferent, or antagonistic. Also, the mixture of the two antibacterial concentrates exhibits a joint effect compared to when used alone. Based on the combination test results, the avocado seeds and ketepeng cina leaves extracts possessed antibacterial activity, however, the inhibition zone results obtained from the blends produced an additive effect. This was deduced as an analysis of the samples performed respectively at various proportions generated slightly weaker activities in contrast with the unmixed extracts (Figures 1 and 2) [14].

The chemical constituents of ketepeng cina leaves (C. alata) such as 1,3,8, trihydroxy-6-methylanthraquinone, 3,4-dihydroxycinnamic acid, kaempferol-O-diglucoside, quercetin-O-glucoside, kaempferol-O-glucoside, kaempferol, rhein, and others [9], as well as catechin, epichatecin, procyanidin trimer A, unsaponifiable fatty acid, and others [4] are components of avocado seed might be responsible in this activity.

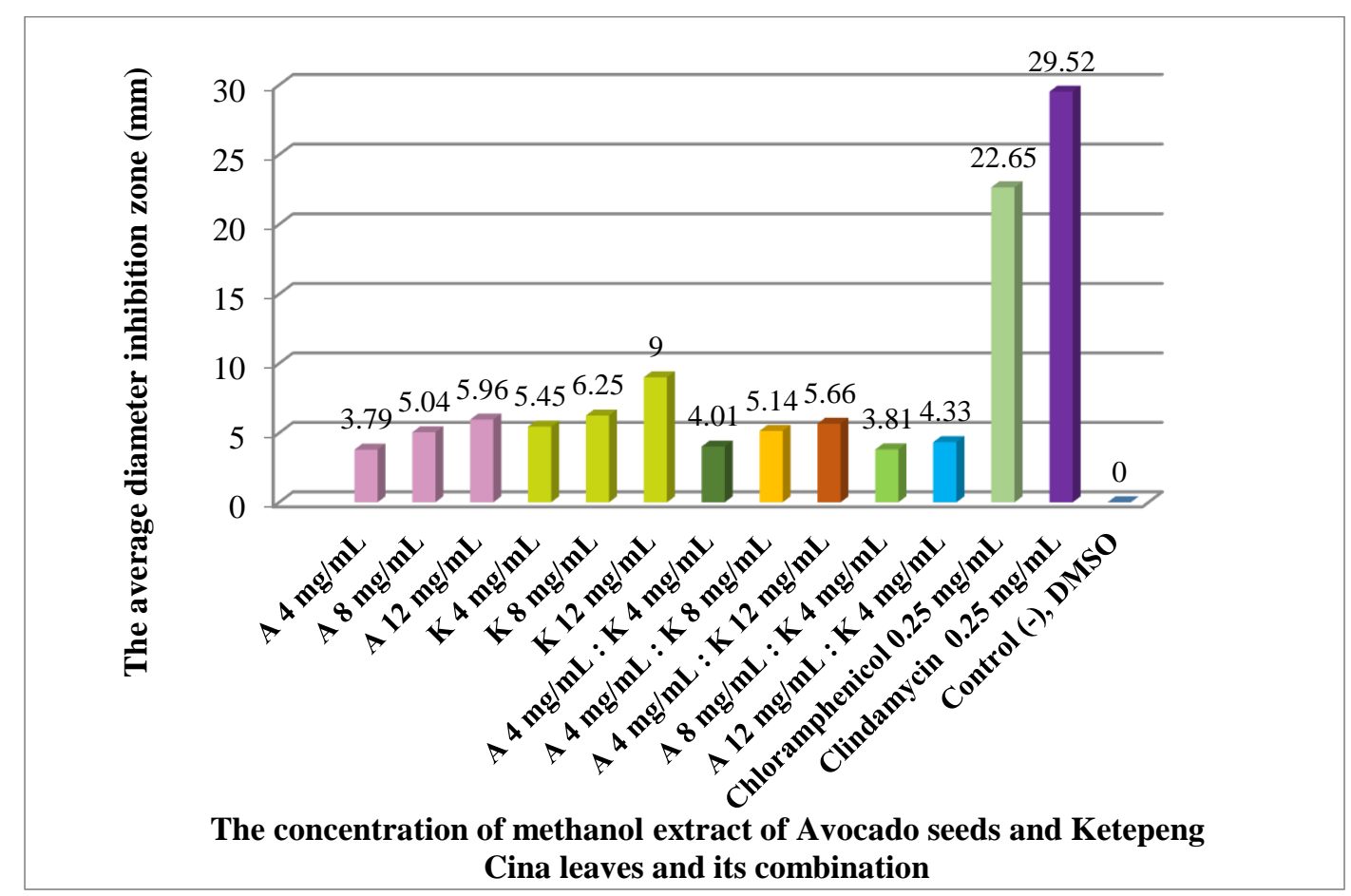

Figure 2. The graph of the relationship between extract concentrations in several combinations of test with an average growth inhibition diameter for Staphylococcus epidermidis on paper disc. Note: A = Avocado; K = Ketapang Cina

Further investigation are needed to understand the best combination of isolated compounds from both this plant. The concomitant administration of two or more drugs is imperative in combination with drug therapy and requires utmost consideration to achieve the desired therapeutic goals or treat existing diseases simultaneously.

The interaction properties were observed in the combination of both test extracts by using the paper strip diffusion [15]. This technique was 
employed to determine antibacterial activity through observation of patterns formed in each substance, where the paper strips were placed on the media to form a $90^{\circ}$ angle. Subsequently, all variations of the combined methanol extract mixture of avocado seeds and ketepeng cina showed the indifferent (additive) effect whereas two oval areas of inhibition joining at left angles. Furthermore, the interaction between both concentrates shows an indifferent response when used together to hinder the growth of S. epidermidis. In addition, results obtained showed the pattern formed when these characteristics were tried with the paper strip method was similar to the combination test mixed directly between both concentrates.

\section{CONCLUSION}

The methanol extracts of avocado seed $(P$. americana) and ketepeng cina leaves ( $C$. alata) mixture inhibits the growth of $S$. epidermidis at various concentration combinations. This was marked by the presence of clear zones around the disc paper. Furthermore, the combination application resulted in a slightly weaker activity compared to individual use. This effect is an indifferent or additive or no interaction corresponds in the inhibition of acne-causing bacteria. Therefore, a combination of crude methanol extract of avocado seeds and ketepeng cina is not recommended to hinder the growth of $S$. epidermidis.

\section{REFERENCES}

[1] P. Ravisankar, O.S. Koushik, V. Himaja, J. Ramesh and P. Pragna, 'Acne-causes and amazing remedial measures for acne', Indo Am. J. Pharm. Res., vol. 5, no. 07, pp. 25122522, 2015.

[2] S. Bhuchar, R. Katta, and J. Wolf, 'Complementary and alternative medicine in dermatology', Am. Clin. Dermatol., vol. 13, no. 5, pp. 311-317, 2012.

[3] S. Chanda, and K. Rakholiya, 'Combination therapy: synergism between natural plant extracts and antibiotics against infectious diseases', Microbiol Book Series, 1, Formatex pp.520-529, 2011.

[4] D. Dabas, R.M. Shegog, G.R. Ziegler, and J.D. Lambert, 'Avocado (Persea americana) seed as a source of bioactive phytochemicals', Curr. Pharm. Des., vol. 19, no. 34, pp. 61336140, 2013.

[5] J.J.G. Leite, É.H.S. Brito, R.A. Cordeiro, R.S.N. Brilhante, J.J.C. Sidrim, L.M. Bertini, S.M. Morais, and M.F.G. Rocha, 'Chemical composition, toxicity and larvicidal and antifungal activities of Persea americana (avocado) seed extracts', Rev. Soc. Bras. Med. Trop., vol. 42, no. 2, pp. 110-113, 2009.
[6] T.W.R. Chia, and G.A. Dykes, 'Antimicrobial activity of crude epicarp and seed extracts from mature avocado fruit (Persea americana) of three cultivars', Pharm. Biol., vol. 48, no. 7, pp. 753-756, 2010.

[7] E. Julianti, K.K. Rajah, and I. Fidrianny, 'Antibacterial activity of ethanolic extract of cinnamon bark, honey, and their combination effects against acne-causing bacteria', Sci. Pharm., vol. 85, np. 19, pp. 1-8, 2017.

[8] S.T. Saito, D.D.S. Trentin, A.J. Macedo, C. Pungartnik, G. Gosmann, J.D.D. Silveira, T.N. Guecheva, J.A.P. Henriques, and M. Brendel, 'Bioguided fractionation shows Cassia alata extract to inhibit Staphylococcus epidermidis and Pseudomonas aeruginosa growth and biofilm formation', Evid. Based Complement. Alternat. Med., pp. 1-13, 2012, doi:10.1155/2012/867103

[9] J. Meenupriya, A. S. Vinisha, and P. Priya, 'Cassia alata and Cassia auriculata-Review of their bioactive potential', World J. Pharm. Sci., vol. 2, no. 12, pp. 1760-1769, 2014.

[10] N. F. Kurniati, A.N. Garmana, and N. Aziz, 'Aktivitas antibakteri dan antijamur ekstrak etanol akar, bunga, dan daun turi (Sesbania grandiflora L. Poir)', Acta Pharmaceutica Indonesia, vol. 42, no. 1, pp. 1-8, 2017.

[11] V. Anggaraini, and M. Masfufatun, 'Efektivitas kombinasi ekstrak daun sirih merah (Piper crucatum) dan ekstrak biji alpukat (Persea americana) dalam menghambat pertumbuhan Candida albicans', Jurnal Kimia Riset, vol. 2, no. 2 pp. 86-92, 2017.

[12] A.G. Ponce, R. Fritz, C. Del Valle, and S.I. Roura, 'Antimicrobial activity of essential oils on the native microflora of organic Swiss chard', LWT-Food Sci. Technol., vol 36, no. 7, pp. 679-684, 2003.

[13] M. Otto, 'Molecular basis of Staphylococcus epidermidis infections. Semin', Immunopathol. vol. 34, no. 2, pp. 201-214, 2012.

[14] R. R. Gupta, 'Topics in Heterocyclic Chemistry', Verlag Berlin Heidelberg, 2008.

[15] S. Laishram, A.K. Pragasam, Y.D. Bakthavatchalam, and B. Veeraraghavan, 'An update on technical, interpretative and clinical relevance of antimicrobial synergy testing methodologies', Indian J. Med. Microbial., vol. 35, no. 4, pp. 445-468, 2017. 